\title{
Kanatlı Beslemede Güncel Çalışmalar ve Gelecek için Öneriler
}

\author{
Hasan Rüştü Kutlu ${ }^{*}$, Ahmet Şahin ${ }^{2}$ \\ 1 Çukurova Üniversitesi Ziraat Fakültesi Zootekni Bölümü, Adana \\ 2 Ahi Evran Üniversitesi Ziraat Fakültesi Zootekni Bölümü, Kırșehir \\ *İletişim (correspondence): e-posta: hrk@cu.edu.tr, Tel: +90 (322) 3386822 \\ Gönderim tarihi (Received): 10 Ağustos 2017; Kabul tarihi (Accepted): 05 Kasım 2017
}

\section{Öz}

$\mathrm{Bu}$ derlemede, kanatlı besleme konusundaki son araştırmalar ile önerilebilecek yeni besleme ve yemleme uygulamalarına değinilmiştir. Kanatlı beslemede mısır ve soya kullanımını azaltma yönünde çalışmalar ile yeni ham madde arayışları devam etmektedir. Probiyotikler, prebiyotikler, organik asitler, antimikrobiyal ve antioksidant etkili bitkisel ekstraktlar, sindirime yardımcı eksojen enzimler ve toksin bağlayıcılar pek çok araştırmaya konu olmuştur ve olacaktır. Bu kapsamda; inülin, kitosan ve kito-oligosakkaritler, lignoselüloz, fitaz, amilaz, bütirik asit, bitkisel ekstraktlar, odun kömürü ve kuşburnu tozu gibi katkıların kanatlılar üzerindeki olumlu etkileri rapor edilmiştir. Spesifik besin maddelerinin karşılanması, besin maddelerinin embriyonik dönemde verilmesi, üniformitenin sağlanması, sürüde üreme performansının sürdürülebilirliliği, sağlık koruma, sıcaklık stresininin olumsuz etkilerini azaltma, ürün kalitesini iyileştirme ve fonksiyonel gıda üretimine yönelik yeni besleme uygulamalarında yoğunlaşılmıştır. Meta analizleri ile etkilerinde devamlılığ saptanacak ülkemiz tıbbi ve aromatik bitkilerinden yeni tescilli yem katkılarının üretilmesine yönelik çalışmalara ihtiyaç vardır. Yemlemenin modern metodlarından seçmeli yemleme, tüm dane yemlemesi ve grit yemlemesi halen araştırma safhasındadır. Yemlerin fiziksel, kimyasal ve biyolojik analizlerinin yapılması, hızlı analiz yöntemlerinin analitik olarak doğrulanarak kalibre edilmesi ve yaş analiz sonuçları ile uyumluluğunun kontrolü, karma yemlerin daha doğru formüle edebilmesi ve hayvanların yeterli ve dengeli bir şekilde beslenmeleri için oldukça önemlidir. Bunun için, Üniversiteler ile Gıda Tarım ve Hayvancılık Bakanlığı ve Gümrük ve Ticaret Bakanlığının ortak işbirliği ile hazırlanacak alt yapı çalışmaları ile akredite laboratuarlar tesis edilmelidir. Sonuç olarak, gelecekte yürütülecek çalışmalar; ekonomik kriterler, alternatif yem bitkilerin belirlenmesi ve kültüre alınması, yeni yem katkılarının üretilmesi, sürdürülebilirlik ve ürün kalitesi düzleminde yol almaya devam edecektir. Ancak, kanatlı besleme çalışmalarının, teorik bilime ve pratik saha uygulamalarına katkı sağlama yanında; ülkemiz gündemini sürekli meşgul eden GDO gibi tartışmalı konuları aydınlatıcı, hayvan refahı, tüketici sağlığı ve ekolojik dengenin korunmasına da katkı sağlayıcı olması beklenmektedir.

Anahtar kelimeler: Kanatlı besleme, yeni yemler, yeni teknolojiler, sağlık koruma, ürün kalitesi

\section{Recent studies and recommendations for future in poultry nutrition}

\begin{abstract}
In this review, it was mentioned that the recent studies and new nutrition \& feeding practices suggested in poultry nutrition. The studies on the ways of reducing of soya and maize in poultry diet and seeking new alternative feed raw materials have been carried out. Probiotics, prebiotics, organic acids, antimicrobials and antioxidant effective plant extracts, digestive stimule exogen enzymes and toxin binders have been subject for the recent studies, in future too. In this context, the positive outcomes of inulin, chitoshan and chito-oligosaccharides, lignocellulose, phytase, amylase, butyric acid, plant extracts, charcoal and roseship powder on poultry have been reported. Studies have been focused on maintaining specific nutrients, offering nutrients during hatching, maintaining uniformity, sustain fertility in the flock, health protection, eliminating the negative effects of heat stress, incerasing food quality and producing functional foods. As modern feeding methods, choice feeding, whole grain feeding and grit feeding have been studied to improve animal welfare. There has been need for new studies conducted to produce new feed additives by using our local medicinal and aromatic plants whose sustainable effects determined by meta analysis. The physical, chemical and biological analysis of feeds, the calibration and confirmation of fast feed analysis analytically and controlling their compatibility to fresh analysis are great importance for a true formulation of compound feed and a sufficient and balanced nutrion for farm animals. For this aim, an accredited feed-food analysis labs should be founded by coordinative infrasturacture works with Republic of Turkey Ministry of Food, Agriculture and Livestock and Ministry of Customs and Trade. In conclusion, future poultry nutrition studies are going to be continued on the plane of economical criteria, determination of alternative feed stuffs and their cultivations, production of new feed additives, sustainability and food or product quality. However, poultry nutrition studies are expected to contain not only pure and applied nutrition but also to answer and to enlighten the discussed issues in our country such as GMO, and also to support animal welfare, consumer health and ecological equilibrium.
\end{abstract}

Keywords: Poultry nutrition, new feeds, new technologies, health protection, product quality 


\section{Giriş}

Ülkemiz hayvancılığının gelişmesi için yüksek verimli ırkların kullanılması yanında hayvanların besin madde gereksinimlerini yeterli ve dengeli bir şekilde karşılayacak rasyonlarla beslenmeleri gerekmektedir. Yumurta, piliç eti ve hindi eti üretiminde kullanılan hibritlerin çok sayıda besin maddesine duydukları gereksinmelerin bir iki yemle karşılanmasının olanaksız olduğu, besleme olayında salt besin madde gereksinmelerini karşılamanın yeterli olmadığı, bunlar arasındaki oran veya dengelerin de mutlaka dikkate alınması gerektiği günümüzün tartışmasız bir gerçeğidir. Kanatlı üretiminde ve ürünlerinde yaşanan kayda değer artış, tesadüf değil, genetik ilerleme yanında besleme, yem ve yem teknolojisindeki gelişmeler ile yakından ilişkili olup çoklu disiplinler arası çalışmalarının ortak çıktısıdır (Şekil 1).

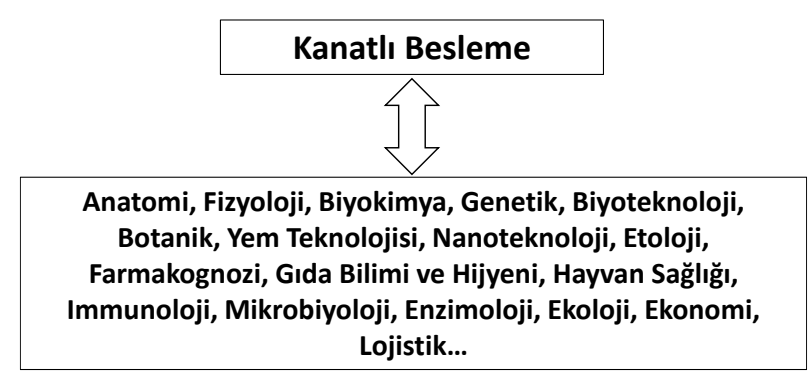

Şekil 1. Kanatlı besleme ile ilgili disiplinlerden bazıları

Son yıllarda kanatlı beslemede; lifli yemler, siralı ve seçmeli yemleme, nişasta sindirilebilirliliği, incebağırsak epitel doku bariyerleri, mikrobiyota ve probiyotik kullanımı, nekrotik enteritte mücadelede yulaf kavuzu ve arabinoksilo oligosakkarit kullanımı, bitki esans yağları ile dış parazit mücadelesi, nano iz element beslemesi, koksidiyoz ile mücadelede mikrokapsül içinde organik asit ve bitki esans yăg karışımı, pamuk tohumu küspesi ile birlikte enzim kullanımı, buğdaya dayalı tavuk yemi, karbohidraz takviyeli ayçiçeği küspesi kullanımı, yumurta kabuğu sağlamlılığı için manganez kullanımı, sicaklık stresinin olumsuz etkisini önlemede polifenoller ve sentetik karotenoidler, salmonella ile mücadelede isoquinoline alkaloidleri, vitamince zenginleştirilmiş yumurta üretimi ve sürdürülebilir tavukçuluk konuları öne çıkmaktadır. Oldukça geniş yelpazede yürütülen bu çalışma konularını ancak kitap veya kitap serisinde toplamak mümkündür. Bu yüzden, bu derleme, kanatlı (etlik piliç, yumurta tavuğu, damızlık tavuk, hindi, kaz, ördek ve bıldırcın) üretimi için her geçen gün önemi daha da artan yem, yem teknolojisi ve besleme alanında elde edilen başarının sürdürülebilmesi için gelecek yıllarda ülkemizde ihtiyaç duyulan araştırma konularının irdelenmesi ve öneri oluşturulması amacıyla, aşağıdaki başlıklar altında sunulmuştur.

\section{Alternatif Yem Kaynaklart}

Kanatlı karma yemlerinin hazırlanmasında gereksinim duyulan enerji ve protein kaynaklarının sürdürülebilir şekilde sağlanması oldukça önemlidir. Mısır ve buğday gibi enerji içeriği yüksek tahıl kaynakları açısından belli oranda yeterli olan ülkemiz, özellikle kaliteli protein kaynakları açısından ithalata mahkûmdur. Ülkemiz koşullarında üretimi yapılabilecek kanatlı karmalarında kullanımı mümkün aspir, ketencik gibi yağlı tohumların küspeleri ile guar, çemen, lüpen, vb. gibi alternatif protein kaynağ 1 yemler üzerinde araştırmalara ihtiyaç vardır. Örneğin; tıbbi ve aromatik bitkilerden çemenin, yüksek antioksidant kapasitesi, antidiyabetik, antikolesteromik, hipoglisemik etkileri ve daha bir çok farmakognozi özelliklerinden dolayı (Olaiya ve Soetan, 2014; Singletray, 2017) hem yem hammaddesi ve hem de yem katkısı olma potansiyeli vardır. Bu kaynakların yem değerlerinin artırılması amacıyla eksojen enzim desteğinde kullanımı da özel olarak irdelenmelidir.

Artan misır üretimine rağmen, önemli miktarda ithalatının (2015 ve 2016 yillarında toplam 2 milyon ton) halen yapılıyor olması, yerine diğer tahılların daha fazla oranda ikamesini zorunlu kılmaktadır. Zira, yaklaşık 7 milyon ton misır tüketimimizin \%76'sını sadece yem sektörü değerlendirmektedir (TMO, 2016). Bu bakımından, enerji değeri bakımından mısır danesine yakın olan sorgumun kanatlı hayvan beslemede kullanılabileceği, seçmeli yemleme çalışmaları ile de doğrulanmıştır. Sorgumla beslemenin mısırla beslemeye oranla ayak dermatitisin vakalarını azalttığına dair bulguların (Ferzola ve ark., 2016) da bulunmas1, sorgumun kanatlı beslemede önemini arttırmaktadır. Ayrıca, misırın uygun eksojen enzim kombinasyonları ile birlikte diğer tahıllarla kısmen ikamesine yönelik çalışmalara öncelik verilmelidir.

Genetiği değiştirilmiş yem hammadde kaynaklarının besin madde içerikleri, sindirilebilirlikleri, hayvan sağlığ1 ve ürün kalitesi üzerine etkilerinin irdelendiği değişik çalışmalar yapılmıştır (Korwin-Kossakowska ve ark., 2013; Swiatkiewicz ve ark., 2014). Ancak, bu ürünler hakkında tüketicilerin endişeleri halen giderilememiştir.

Bitkisel protein açığının kapatılmasında, ülkemiz bitkisel üretim desenine uygun yağ sanayi yan ürünlerinin (fındık küspesi, ayçiçeği küspesi, pamuk tohumu küspesi, aspir küspesi, mısır glüten unu) kullanımı öne çıkmaktadır. Yoncanın (yonca unu) ve süt endüstrisi yan ürünlerinin (peynir altı suyu veya tozu, Shariatmadari ve Forbes, 2005) kanatlı yemi olarak kullanımını yaygınlaştırıcı 
yem teknolojiler üzerinde çalışılmalıdır. Ayrıca, protein kısıtı olan ülkelerde kurtçukların dahi \%10-15 oranında kanatl yemlerinde (Hwangbo ve ark., 2009) kullanıldığına dair çalışmalar, alternatif kaynak arayışı çabası olarak karşımıza çıkmaktadır.

Dünyanın farklı kesimlerinde tek midelilerin beslenmesinde kullanılan diğer baklagil daneleri (maş fasulyesi, börülce, nohut vs., Erlwanger ve ark, 1999; Kur ve ark., 2013) ile yaprağı ve tohumundan yararlanılan Moringa oleifera (Abbas, 2013) gibi subtropik bitkiler üzerinde çalışmalar yapılmaktadır. Bu bitkilerin fenolik içeriklerinden dolayı yem hammaddesi ve yem katkısı özelliği taşıyıp taşımadıklarının araştırılmasına da ihtiyaç bulunmaktadır. Güvercin bezelyesinin etlik civciv rasyonunun \%30'u ve börülcenin ise \%15'ine kadar kullanılabileceği ispatlanmıştır (Yagoub, 1998). Küresel 1sınmaya bağlı iklim değişikliklerinden ve besin maddelerince giderek fakirleşen toprak koşullarından daha az etkilenen burçak, mercimek ve çemen gibi yerel yem kaynaklarının hayvan beslemede kullanımının giderek önem kazanması yakın gelecekte beklenmektedir.

Kinoa (Chenopodium kinoa) farklı iklim ve topraklarda yetiştirilebilen kazayağıgiller familyasına ait protein yönünden zengin tek y1llık bir bitki olup son y1llarda ülkemizde de üretilmesine yönelik çalışmalar devam etmektedir. İçerdiği saponinler kullanımını kısıtlayıcı en önemli faktörlerden biridir. Gerek etlik piliçlerin ve gerekse yumurtacı tavukların beslenmelerinde kullanımı farklı bilimsel çalışmalarla (Gül ve Tekçe, 2016) ortaya konulmuş, ancak FAO'nun bir raporuna göre hayvan yemi olarak kullanımının ekonomik olmadığı vurgulanmıştır (Blanco, 2013). Ancak, içerdiği biyokimyasallar ve özellikle saponinlerden dolayı yem katkısı olarak kullanılıp kullanılamayacağı yakın gelecekte bilimsel çalışmalarla ortaya konulabilir.

Biyoyakıt sanayi yan ürünü olan kurutulmuş damıtık tahıl ve çözünür maddeleri (DDGS) kanatlı beslemede protein kaynağı olarak kullanılmasında lizin ile birlikte arjinin ve triptofanın da sınırlı amino asitler olduğu ve etlik piliçlerde rasyonun \%12-15'i, yumurta tavuklarında ise rasyonun $\% 15$ ' $\mathrm{i}$ düzeyinde kullanılabileceği önerilmiştir (Ergül ve ark., 2003). ABD Tahıl Konseyi, bu yem kaynağının çiftlik hayvanlarında kullanımı ile ilgili ayrıntılı bir klavuz hazırlamıştır. Kanatlılar için bu kılavuzda ayrı bir bölüm bulunmaktadır (USGC, 2012). Nişasta tabiatında olmayan polisakkaritlerce zengin olan kanatlılarda sindirilebilirliğinin iyileştirilmesinde eksojen enzim desteğinde kullanımı ekonomik açıdan önemli olacaktır. Ayrıca, bu sanayinin diğer bir yan ürünü olan gliserinin etlik piliç yemlerinde $\% 5$ düzeyinde kullanılabileceği önerilmiştir (Min ve ark., 2008). Artık ülkemiz sanayicileri de yenilenebilir enerji kaynaklarına ilgi duymaktadır. Yakın gelecekte biyoyakıt üretimi sonucunda ortaya çıkan ürünleri ithal etmeden veya daha az ithal ederek hayvan yemlerinde alternatif protein ve enerji kaynağı olarak sunulabilecektir. Ancak, biyoyakıt üretiminden elde edilen bu yan ürünlerden, hayvan beslemede daha etkin bir şekilde yararlanabilmek için; bu ürünlerin kanatlı hayvanların et ve yumurta verimlerini ne şekilde etkilediğinin ve yem formülasyonunda yer alacak optimum miktarlarının belirlenmesini sağlayacak daha fazla sayıda bilimsel çalışma yapılmasına gerek duyulmaktadır.

Tavuk rendering ürünlerinin kanatlı beslemede kullanımının sınırlandırılması (24 Aralık 2011 Tarih ve 28152 Sayılı Resmî Gazetede Yayımlanan "İnsan Tüketimi Amaciyla Kullanılmayan Hayvansal Yan Ürünler Yönetmeliği”) ile yem sektöründe (2017 Ocak ayından itibaren ilave doğan) protein açığının kapatılmasında, üç tarafi denizle çevrili ülkemizde, "balık unu" kullanımını daha ucuz hale getirici işleme ve tedarik yollarının araştırılması ve geliştirilmesi zorunludur.

\section{Yem Teknolojisi}

Kanatlı yemlerine uygulanan teknolojik işlemler içinde öğütme-kırma-ezme, peletleme, ekspand veya ekstrude etme ve son zamanlarda pastörize sicaklık uygulaması büyük öneme sahiptir. Ekspander veya ekstruder ile işlemenin yem nişastasında jelatinizasyonu sağlayarak yemlerin sindirilebilirliğini ve lezzetini artırdığı, yağlı tohumlardaki anti-besinsel faktörlerin yıkımını sağladığ ve yem kalitesini artırdığı kesin kabul edilmiş bir gerçektir (Kutlu ve Çelik, 2016).

Peletlemede buhar sıcaklığının yükseltilmesi, buğdaysoya esaslı karma yemin pelet dayanıklılığını (Abdollahi, 2011), yemin ileumda kalış süresini, nişasta ve protein sindirimini ve glukoz emilimini arttırmıştır (Liu ve ark., 2014). Peletleme teknolojisi ile birlikte ileal besin madde (nişasta ve protein) sindirilebilirlik çalışmalarının, sorgumda olduğu gibi diğer yem maddeleri için de çalışılması gerekir.

Çimlendirilen baklagil danelerinde anti-besinsel faktörlerin azaldığına dair araştırma bulguları (Malomo, 2013) ve çimlenme ile dane (tohum) biyokimyasındaki değişiklikler, ülkemizde "çimlendirme"nin ayrı bir yem teknolojisi olarak çalışılması gerektiğini ortaya koymaktadır. Ayrıca, çimlendirilecek gerek hububat ve gerekse baklagil danelerinin çimlenmeyi takiben 
kurutulup un veya toz haline getirilerek yeni teknolojik yem ham maddelerinin ve yem katkılarının üretilmesinin önü açıktır.

Mikroalgler, kanatlı beslemede hem protein kaynağ1 ve hem de yumurta ve etin pigmentasyonu ve besin değerinin arttırılmasında kullanılmıştır (Świątkiewicz ve ark., 2015a). Ayrıca, Gorski ve ark. (2015) tarafindan alglerin peletleme öncesi karışıma dahil edilmesinin pelet yemlerde dayanıklılığı arttırdığı ortaya konulmuştur. Tavuk dışkısı besi ortamında üretilen spirulananın yumurtacı tavukların beslenmesinde pigment kaynağ olarak kullanımı konusunda Çukurova Üniversitesi'nde bir doktora çalışması halen devam etmektedir.

\section{Etkicil Maddeler}

Hayvan beslemede etkicil madde olarak tanımlanan kaynaklar temelde iz mineraller, vitaminler ve esansiyel amino asitler olmak üzere üç temel grupta incelenmektedir. Kanatlı hayvanlarının iz mineral ve vitamin gereksinimleri, ilgili standartlar esas alınarak hazırlanan premikslerin yeme ilavesiyle karşılanmaktadır. $\mathrm{Bu}$ alandaki öncelikli çalışmalar; özellikle farklı formlarda üretilip piyasaya arz edilen iz minerallerin, vitaminlerin ve esansiyel amino asit kaynaklarının biyoyarayışlılıkları, stabiliteleri ve ekonomik etkinliklerini kapsamalıdır.

Selenyum günümüzde fonksiyonel gida üretiminde yaygın olarak kullanılan bir iz elementtir. Son yıllarda yapılan çalışmalarla selenyumun et ve yumurta kalitesi, antioksidan kapasite ve bağışıklık sistemi üzerine olumlu etkileri ispatlanmıştır (Suchy ve ark, 2014). Bu elementin gerek nano partiküllerinin ve gerekse organik formlarının kanatlı beslemede kullanımını arttırıcı çalışmalara gereksinim vardir.

Gümüş (Özcan, 2014) ve kromunun (Hamidi ve ark., 2016) nanopartiküllerinin kanatlı beslemede sağlık koruma ve sicaklık stresini azaltma yönünde kullanılması, iz elementlerin yemdeki formlarının araştırılmasına yönelik yeni çalışmalara 1şık tutmaktadır.

Kanatlı beslemede önemli olduğu bilinen diğer iz elementlerin esansiyellikleri konusunda pek çok temel çalışma yapılmıştır. Son yıllarda, yeryüzünde çok az bulunan ultra iz elementler grubunda yer alan cerium (Bölükbaşı ve ark., 2016) ve lanthaniumun yumurtacı tavuklarda yem katkısı olarak kullanılabileceği bildirilmiştir (Durmuş ve Bölükbaşı, 2015). Temininin kolay ve ucuz olması durumunda; diğer ultra iz elementler (scandium, yttrium, praseodymium, neodymium, promethium, samarium, europium, gadolinium, terbium, dysprosium, holmium, erbium, thulium, ytterbium ve lutetium) üzerinde de çalışılabilir.

\section{Yem Katkı Maddeleri}

Çiftlik hayvanlarının beslenmesinde, normal yetiştirme koşullarında gereksinim duyulmayan, fakat yeme katıldıkları zaman yemlerdeki besin maddelerinin hayvanlara bozulmadan ulaşmasını, hayvan tarafindan daha kolay sindirilmesini ve bağırsaklardan emilip vücut hücrelerine taşınmasını sağlayan, ürün miktarını artıran, yemden yararlanmayı iyileştiren, ürünün görünümünü değiştiren, niteliğini etkileyen, kalitesini yükselten veya bir başka nedenle ekonomik yarar sağlayan "Yem Katk1 Maddeleri", son yıllarda en çok tartışılmakta ve üzerinde yoğun araştırmalar yapılmaktadır (Kutlu ve Özen, 2009). Antibiyotik kökenli büyüme uyarıcıların yem katkı maddesi olarak kullanımlarının yasaklanmasından dolay1; probiyotikler, prebiyotikler, organik asitler, antimikrobiyal ve antioksidan etkili bitkisel ekstraktlar, sindirime yardımc eksojen enzimler ve toksin bağlayıcılar üzerinde halen çalışmalar devam etmektedir. $\mathrm{Bu}$ konuda binlerce araştırmayı bu derlemede özetlemek mümkün görülmemektedir. Ancak, bazı yem katkıları hakkında elde edilen araştırma bulguları aşağıda sıralanmıştır.

Hindibadan elde edilen inülinin, sindirim kanalında bifidobacteria, lactobacilli ve bütirik asit üreten yararlı bakterileri seçici olarak uyardığı, villi uzunluğunu arttırarak emilim yüzeyini artırdığı, bağırsak içeriği ve dışkıda pH'ı düşürerek asidik ortam yarattığı, kolesterol atılımını artırdığı ve dışkıda amonyak konsantrasyonunu azalttığı bildirilmesine (Keser ve Bilal, 2010) rağmen; bağırsak sağlığını destekleyici bu etkilerin metabolizma ve performansa yansımaları konusunda daha kapsamlı araştırmalara ihtiyaç bulunmaktadır. Kitosan ve kitooligosakkaritlerin etlik civcivlerin büyüme performanslarına olan olumlu etkileri yanında bağışıklık düzenleyici, antioksidant, antimikrobiyal ve kolesterol düşürücü etkilerinin olduğu tespit edilmiştir (Światkiewicz ve ark., 2015b).

Kheravii ve ark.(2016), buğday ve mısıra dayalı rasyonlara lignoselüloz (10 $\mathrm{kg} /$ ton $)$ eklemek suretiyle etlik civcivlerin sekumlarındaki yararlı laktik asit ve bütirik asit oranını arttırmışlardır. Ayrıca, buğday esaslı ve lignoselülozlu yemle beslenen civcivlerin sekumlarında misır esaslı rasyonla beslenenlere nazaran daha fazla oranda bütirik asit tespit edilmiştir ki, buradan herhangi bir yem hammaddesi ve yem katkısı arasında etki bakımından interaksiyonların olabileceği sonucu çıkmaktadır. 
Fitazın üretilmesi, etki mekanizmaları, hayvanlar üzerindeki etkileri incelendiğinde (Olukosi, 2012; Kathirvelan ve ark., 2015), bu enzim ile ilgili çalışmaların daha da devam edeceği görülmektedir. Enzim kullanımında yeni bir yaklaşım olan aşırı doz kullanımı çalışmalarından biri fitaz enziminin normal uygulanması gereken dozdan 6 katı ile yapılmış ve etlik civcivlerin büyüme performansının arttığı (Smith ve ark., 2016) görülmüştür. Aynı şekilde, etlik civciv rasyonlarında ksilinaz, glukanaz ve pektinazın önerilen dozu iki misli kullanmanın, rasyonda protein ve amino asit kullanımını \%3 düzeyinde azalttığına (De Keyser ve ark., 2016) dair bulgular, kanatlı beslemede enzimlerin kullanımında doz arttırımına gidilebileceğini göstermektedir. Farklı kaynaklardan alınıp bir araya getirilerek hazırlanıp kanatlı yemlerine katılan eksojen enzim kokteylleri yerine aynı mikroorganizmaca üretilen eksojen enzim kompleksi kullanımının daha başarılı sonuçlar verdiği bildirilmiştir (Kutlu, 2017). Amilaz enziminin özellikle pelet yemlerle birlikte verilmesinin protein sindirilebilirliğini arttırdığına (Schramm ve ark., 2016) dair bulgular enzim kullanımı ile yem işleme teknolojisi çalışmalarından farklı sonuçlar elde edilebileceğini göstermektedir. Etlik civcivlerin rasyonlarında, ton başına $250 \mathrm{~g}$ sistin proteaz kullanımı, soya fasülyesi küspesi kullanımını $20 \mathrm{~kg} /$ ton ekonomize ettiğine dair (Gupta ve Mehta, 2016) bulgular, enzimlerin pahalı yem ham maddelerin rasyonda daha az kullanılmalarına dair yapılacak yeni çalışmaların yönünü belirlemektedir. Dida (2016) tarafından, kanatlılarda enzim kullanımı etki mekanizmaları, besleme manejmanı ve sürü yönetimi bakımından detaylıca irdelenmiştir.

Robinson ve ark.(2016), bütirik asit ve ticari bir bitkisel ekstrakt kullanarak yaptıkları nutrogenomik çalışmada, bu iki katkının antibiyotiklere alternatif olma potansiyelini dile getirmişlerdir.

Kanatlı beslemede toksin bağlayıcı yada absorbant olarak bitki kaynaklı kömür kullanımı (Kutlu et al., 2001) hala güncelliğini koruyan bir konudur. Odun kömürünün yumurtacı tavuklarda kırık yumurta oranını azaltmakta olduğu bilinmektedir. Kana ve ark. (2012)'nın bitkisel kömür katkısının aflatoxin $B_{1}{ }^{\prime} i$ bağladığı ve etlik civcivlerde performansı arttırdığına dair yeni bulgular, daha fazla çalışmanın yapılması gerektiğini ortaya koymaktadır.

Ticarileşmiş kekik, yukka, oregano ve tarçına ilave olarak çemen, çakşır, nane, sumak, çörek otu, biberiye, rezene, keçi boynuzu, defne, mersin, zeytin yaprağı ve zencefil gibi ülkemizin sahip olduğu tüm tıbbi ve aromatik bitkiler ile üzüm çekirdeği ve kabak çekirdeğinden elde edilen özütlerin kanatlılar üzerindeki etkileri meta analizleri ile değerlendirilerek ticarileştirmeye aday olanların tek başlarına veya kombinasyonlar halinde daha fazla hayvan üzerinde etkileri test edilip, tescil ve seri üretimle ekonomiye kazandırılması ve yem katkı maddeleri ithalatının azaltmasına katkı sağlanabilir. Örneğin, Anadolunun doğal bitkilerinden olan kuşburnunun tozunun antioksidant gücü arttırıcı (Vlaicu ve ark., 2017) ve mersin yaprağının ise kolesterol düşürücü ve villi besleyici özelliği olduğuna (Tunçer, 2012) dair bulgular mevcuttur. Yukarıda bahsedilen çoğu bitkinin bünyesinde bulunan fenol, diterpenoid lakton ve fenilpropanoidlerin karışımı ticari antibiyotiklere alternatif olduğu saptanmıştır (Chabrillat ve ark., 2017).

Yukarıda bahsedilen bitkilerden, ticari patentli veya tescilli ve gerek ülkemizde ve gerekse yurt dışında dolaşımını sağlayacak yeni yem katkısı kokteylerin tavukçuluk sektörünün kullanımına takdim edilmesine dair çalışmalara ihtiyaç vardır.

\section{Yeni Besleme Uygulamalart}

Dünyanın birçok ülkesinde olduğu gibi, ülkemizde kanatlıların besin madde ihtiyaçlarında ve yem ham maddelerin besin madde içeriklerinde temel alınan kaynak NRC (1994) ve damızlıkçı firma bildirişleridir. Geçen 23 yılda, hem tavukların hem de yem kaynağı olan bitkilerin genetiğindeki değişiklikler ve iyileşmeler dikkate alınarak, kanatlı besleme için yem ham maddelerin güncel besin madde içerikleri ile genetik ilerleme gösteren mevcut hayvanların güncel besin madde ihtiyaçlarının yer aldığı yeni bir veri bankasının oluşturulması zorunludur. Ayrıca, kanatlılarda görülen bu genetik ilerlemeye uygun verim performansinın yakalanması için geleneksel besleme metotları yanında yeni besleme uygulamaları önem kazanmaya başlamıştır. Bu uygulamalardan bazıları alt başlıklar halinde aşağıda sıralanmıștır.

\section{Amino Asit Beslemesi}

Kanatlı beslemede, protein beslemesi artık amino asit beslemesi şeklinde olup, bilinen klasik rasyondaki amino asit dengesi, ileal sindirilebilirlilik çalışmaları test edilmektedir. Amino asitler yem katkıları ile birlikte ayrıca rasyona katılarak etkileri araştırılmaktadır. Amino asit beslemesindeki son gelişmeler, Beski ve ark. (2015) tarafindan detaylıca irdelenmiştir. Günümüzde, yem ham maddelerinin amino asit miktarı ve çeşitliliğindeki yetersizlikleri, ticari olarak daha kolay ve ucuz üretilen sentetik amino asitlerle kapatılmaktadır. $\mathrm{Bu}$ amino 
asitlerin yem hammaddesi olarak, yem karmalarına ideal amino asit oranlarının sağlanması için girişleri yaygınlaşmıştır. Gelecekte, amino asitlerin, enzim, bitkisel ekstrakt, iz element, vitamin, prebiyotik ve probiyotik ile birlikte eş zamanlı kullanımına yönelik çalışmalar, kanatlı beslemede biyoyararlılığın arttırılmasına yardımcı olacaktır.

\section{In ovo Besleme}

Kanatlı hayvanlarda in ovo besleme yöntemi son yıllarda önemle üzerinde durulan araştırma alanlarından biri olmuştur. İnkübasyon dönemindeki kanatlı embriyolarının keselerine karbonhidrat, amino asit ve çeşitli protein içeriklerine sahip sıvı solüsyonların enjeksiyonu esasına dayanan bu yöntem kolay olmayı, teknolojik uygulama gerektirmekle beraber, klasik beslemeye göre, hayvanın sindirim sistemi gelişimi üzerine olumlu etkiye sahiptir (Uni, 2003). Bağırsak gelişimi, iskelet sağlığı, glikojen birikimine, canlı ağırlık artışına, bağışıklık sisteminin gelişmesine ve epigenetik programlamaya olan olası etkileri sadece et tavuğu yumurtaları için değil, hindi ve diğer kanatlıların döllü yumurtaları (Bohŏrquez, 2010) için de çalışılmaya açık konulardır.

Singh ve ark (2016) yaptıkları in ovo çalışmada inkübasyonun 12.gününde döllü yumurtanın hava boşluğuna raffinoz enjeksiyonunun kuluçka randımanının arttırma yanında etlik civcivlerde bağışıklık sistemlerini güçlendirdiğine dair bulgular elde etmiştir.

Ahi Evran Üniversitesi Ziraat Fakültesi Zootekni Bölümündeki in ovo besleme çalışmalarında, polen ekstrakt1, mannan oligosakkarit (MOS) ve maya karışımı, lizin ve metiyonin aminoasitleri denenmiş olup lizinin kuluçka randımanını arttırıcı, polenin probiyotik gibi etki gösterdiği ve sekumda laktik asit bakterilerini arttırdığına dair bulgular (Çoşkun ve ark., 2014ab; Erener ve ark., 2015; Çoşkun ve ark., 2017) diğer etkicil maddelerin ve bitkisel ekstraktların da in ovo beslemede kullanılabileceğini göstermektedir.

\section{Üniformite Beslemesi}

Damızlık sürülerde hedef canlı ağırlığa göre besleme olarak tanımlanan, gün boyunca küçük ara öğünler halinde hayvanların birbirleri ile yem yarışına girmemelerini sağlamak suretiyle sürüde üniformiteyi sağlayan ve ingilizcesi "precision feeding" olan bir besleme yöntemidir. $\mathrm{Bu}$ besleme yöntemi ile damızlık sürülerde üniformitenin, bir gün aç bırakma uygulamasına göre daha iyi sağlandığına dair bulgular (Carneiro ve ark., 2015) mevcuttur. Ülkemizde damıllk kanatlı yetiştiriciliğinde damızlık hayvanların beslenmesinde, yemleme menajmanına dair çalışmalar oldukça yetersizdir. Ayrıca, damızlık sürülerde doygunluk sağlayıcı yem ham maddelerin (baklagil danesi) damızlık tavuk yemlerinde kullanılmasına (Deep ve ark., 2015) yönelik çalışmaların arttırılması canlı ağırlığın kontrolü bakımından ayrı bir önem taşımaktadır.

\section{Kalite İyileştirici Besleme}

Kanatlılardan elde edilen başlıca ürünler, sofralık yumurta, kuluçkalık yumurta, et, civciv ve spermadır.

Sofralık yumurtanın iç ve dış kalitesi besleme aracılığıyla iyileştirilebilir. Yumurtanın kabuk kalınlığı ve direnci, ak ve sarının miktar ve görünümü, sarı rengi, et-kan lekesi ve besin madde içeriğinde beslemenin etkisi kaçınılmazdır. Kalsiyum kaynağının partikül büyüklüğü ve yemleme zaman1, optimum $\mathrm{Ca} / \mathrm{P}$ oranı, D vitamini, çinko, bakır ve mangan ilavelerinin doğrudan; kolin, folik asit ve $\mathrm{B}_{12}$ vitamininin dolaylı olarak, yumurta kabuk kalitesine etkileyen bilinen faktörlerdir. $\mathrm{Bu}$ konuda, uygun yemleme zamanının saptanması, seçmeli yemleme ile farklı kalsiyum kaynaklarının yumurtlayan tavuklara sunulması ve bu çalışmaların fitaz enzimi uygulamaları ile entegrasyonuna yönelik yeni çalışmalara ihtiyaç duyulmaktadır.

Yumurta sarısının tüketici isteğine uygun doğal görünümüne, yemin karoten içeriği, kullanılan sentetik ve doğal pigmentler veya domates ekstraktı likopen yardımıyla ulaşabileceği defalarca ispatlanmıştır. Yumurta kolesterol içeriğini düşüren bir çok mineral, vitamin ve bitkisel ekstraklara son yıllarda zeytin yaprağ 1 ekstarktı oleorepin de (Çayan ve Erener, 2015) eklenmiştir.

Yumurtacı tavukları, gereksinim fazlası 25 hidroksi kolekalsiferol (Hy-D) beslemesi, kabuk kalitesi yüksek (XL) yumurta sayısını arttırmıştır (McDowell ve Ward, 2011). Vitellin zarının sertliği, yumurtanın işlenmesi aşamasında akı ve sarısının ayrılmasında önemli olduğundan özellikle sıcaklık stresi altındaki tavukların yemine $\mathrm{E}$ vitamini takviyesinin bu zarın sertliliğini arttırdığ1 rapor edilmiştir (Galea, 2011). Bu çalışmalar, yumurta işleme kalitesinin tesisi için de vitaminlerin ne derece önemli olduğunu göstermektedir.

Kanatlı etlerinin raf ömrünü uzatmak için son zamanlarda kanatlı yemlerinde kullanılan antioksidant özelliğe sahip tıbbi ve aromatik bitkilerin özütleri veya öğütülmüş tozlarının kullanımı giderek yaygınlaşmaktadır. Ayrıca, yenilebilir mantar atığı 
kanatlı etinin raf ömrünü arttırmıştır (Mazaheri ve ark., 2014). Son zamanlarda, et kalitesi üzerindeki çalışmalar pektoral kas kitlesi ve çapınının arttırılmasına yönelik normal ve in ovo besleme uygulamaları (Maiorano ve Bednarczyk, 2016) ile ilgili olup, bu konudaki çalışmaların histoloji bilimi desteği ile sürdürülmesi öngörülmektedir. Ayrıca, serbest dolaşımlı tavukçulukta hayvanların otlayacağı alanların teşkilinde yonca gibi baklagil yem bitkilerinin kullanılması ile elde edilecek yumurta ve tavuk etinin omega 3 ve 6 , karoten ve E vitaminince zengin olabileceği Spencer (2013) tarafından detaylıca bildirilmiştir.

Kuluçkalık yumurtanın damızlık özelliği, kalitesi ve elde edilen civcivin kalitesi maternal besleme ve/veya erken dönem besleme aracılığıyla iyileştirilebilir. Embriyonun yumurta içinde kalış süresi, kesim yaşı dikkate alındığında neredeyse yumurtadan çıkıştan sonraki ömürlerinin yarısı kadardır. Bu yüzden kuluçkalık yumurtanın besin madde yükünün ve kabuk kalitesinin, sağlıklı civciv eldesine yönelik dizayn edilmesi gerekir. Bunun için son zamanlarda, maternal besleme ile kuluçkalık yumurtaların omega-6 (n-6) ve omega-3 (n-3) yağ asitlerince zenginleştirilmesinin embriyonun enerji ihtiyacının karşılanması yanında büyüme, bağışıklık ve merkezi sinir sisteminin gelişmesi için elzem olduğuna dair çalışmalar (Cherian, 2015), diğer etkicil maddeler ile desteklenmelidir. Ayrıca kuluçka çıkışını takiben yapılan erken dönem besleme uygulaması ile civcivlerin fiziksel ve fizyolojik gelişimini iyileştirilerek özellikle düşük kaliteli civcivlerin ileriki dönem besi performansını veya yumurtlama performansını iyileştirmek olasıdır.

Damızlık horozların üreme performansı ve sperm kalitesi besleme aracılığıyla iyileştirilebilir. Özellikle puberte öncesi (0-12 hafta) rasyon enerji düzeyindeki değişikliklerin horozlarda testis gelişimi, cinsi olgunluk ve semen kalitesine etkileri (Tadondjou ve ark., 2013) çalışılmakla birlikte, vitaminlerin, iz elementlerin, amino asitlerin ve diğer etkicil maddelerin gerek damılık civciv yemlerine ve gerekse horoz yemlerine katılarak, kanatlılarda üreme performansı, semen kalitesi ve döllü yumurta oranını arttırıcı çalışmaların sadece kapalı damızlık işletmelerinde değil, üniversitelerin ve araştırma kuruluşlarının ARGE damızlık kümeslerinde çalışılması, damızlık kanatlı sektörüne uygulanabilir rasyon çözümlemeleri sağlaması açısından önemlidir.

\section{Fonksiyonel Gıda Üretimi İçin Besleme}

Günümüz tüketicilerinin sağlık destek unsurlarını içeren gıdaları tüketme arzularına cevap veren, fonksiyonel özelliğe sahip yem katkılarının hayvanın yemine katılarak ürüne doğal biyolojik yolla geçişini ve birikimini sağlayan bir besleme şeklidir. Bu konuda ülkemizde ve dünyada çalışılan yem katkılarında esas bulgular hayvanlar üzerindeki etkilerine yoğunlaşılmıştır. Şimdiye kadar yapılan çalışmalarda öne çıkan ve ürüne geçişi sağlanan fonksiyonel yem katkıları, A ve E vitaminleri, omega 3 yağ asitleri, konjuge linoleik asit ve selenyumdur. Tüm tıbbi ve aromatik bitkilerdeki fitokimyasallar, iz elementler, vitamin prekursorları, esensiyel amino asitler ve yağ asitleri zenginleştirme materyali olarak kullanılması olasıdır.

Genelde bitkiler sağlığı koruyan ve vücuda zindelik katan binlerce kimyasal madde içermektedir. Tek başına besin maddesi özelliği taşımayan bu maddeler "fitokimyasallar" olarak adlandirılır ve koruyucu hekimlik ve diger tibbi ve biyolojik disiplinler tarafindan vücut savunmasında kullanılan bir süper cephane gibi algılanmaktadır. Kanser, kardiyovasküler sorunlar, hipertansiyon, hormonal bozukluklar ve diyabet gibi sorunların çözümünde izoflavonlar, ellagik asit, fitatlar, indoller, flavonoidler, terpenler, fenolik asit, kumarinler, polifenoller, likopenler, glissirizin, izotiyosiyanatlar, karotenoidler ve sülfitler oldukça önemli fitokimyasallardır (Dündar, 2001). Ancak, bu fonsiyonel etken maddelerin ürüne geçişi ile ilgili izlenebilirlilik çalışmalarına ihtiyaç vardır. Burada esas olan söz konusu etken maddenin hayvanın kan kolesterolünü veya kan şekerini düşürmesi değil, bu hayvanlardan elde edilen fonksiyonel ürünleri tüketen insanlarda bu etkilerin görülmesi beklenmelidir.

Fonksiyonel gıda üretimi için kullanılan yem katkıları hayvanların verimleri yanında sağlıklarına da olumlu etki yapabilir, bu durum verim performansı ve sağlık beslemesi ile ilgilidir. Bu besleme şeklinin gıda işleme teknolojisindeki "terbiye ya da işleme" yöntemlerinden farklı olduğunu da ortaya koyan bilimsel çalışmalara da ihtiyaç bulunmaktadır.

\section{Üreme Beslemesi}

Hayvanların üreme performansını artıran besleme yöntemi olup, kanatlı besleme için düşünüldüğünde, erken dönemde temel besin maddelerini yeterince sağlama yanında, kısıtlı yemleme ile verim için öncelikli organ sistemi olan üreme sistemini gelişmesine firsat tanıyan bir besleme şeklidir. Bu bağlamda, özellikle damızlık civciv, piliç, yarka ve anaçlar, horozlar ile yumurtacı civciv ve yarka ve yumurtalayan tavukların beslenmesi üreme beslemesi olarak değerlendirilebilir. Kanatlı beslemede üreme beslemesinin ana bileşenleri olarak; protein, kalsiyum, inorganik fosfor, linoleik asit, 
E, A ve D vitaminleri, çinko ve selenyumun olduğu şimdiye kadar yapılan çalışmalarla ortaya konulmuştur. Güncel çalıșmalar, bu besin maddelerinden daha fazla yararlanma yönündedir. $\mathrm{Bu}$ bağlamda, örneğin yumurtlayan yumurtacı ve damılık tavuklarda fitaz kullanımı, özellikle üretimin ilerleyen safhasında kemik Ca rezervi bakımından ayrıca önem taşımaktadır.

Üreme vitamini olarak bilinen E vitamini yanında selenyum ve organik bağlı selenyum, horozlardan elde edilen semenin depolama şartlarında kalitesini iyileştirdiğine dair çalışmalar (Surai, 2012) diğer antioksidanlarla desteklenmelidir. Bu çalışmaların gerek horoz yemlerinde ve gerekse elde edilen semenlerin depolama şartlarında daha detaylı çalışılması damızlık kanatlı yetiştiriciliği açısından önem taşımaktadır. Selenyum, E vitamini ve karotenoidlerin maternal besleme ile yumurtaya geçişi ile embriyonun gelişiminin (Surai, 2002a,b) desteklendiği diğer antioksidantların da kullanıldığı yeni çalışmalarla üreme beslemesi alanına önemli katkılar sağlanabilir.

\section{Sağlık Koruma Beslemesi}

Hayvanların sağlığına destek veren ve devamını sağlayan, enfeksiyonlara, kontaminasyonlara ve her türlü hastalık risklerine karşı hayvanları daha dirençli tutmayı amaçlayan bir besleme şeklidir. Yemin besin madde ve çeşiti ile hayvan sağlı̆̆ doğrudan ilişkilidir. Yemin istenmeyen maddeler içermemesi yanında makro ve mikro besin maddeleri bakımından yeterli ve dengeli olması bir çok metabolik ve beslenme hastalıklarının ortaya çıkmasının engellenmesi bakımından önemlidir.

Antibiyotiklere getirilen yasak sonrası yem katkısı olarak kullanılan bir çok ürünler (probiyotik, prebiyotik, bitkisel ekstrakt, esans yağı vb.) kanatlı hayvanlardaki nekrotik enterit, koksidiyosis, Newcastle ve Salmonellayı engellemeye yöneliktir. Bu kapsamda, Caly ve ark. (2015) antibiyotiğe alternatif katkılarla nekrotik enteritin önlenmesi ile ilgili araştırma bulgularını özetlemiştir. Muthamilselvan ve ark. (2016) koksidiyozizi engellemede tıbbi ve aromatik bitkilerin etkilerini detaylı bir şekilde irdelemiştir. Dünyada çok önemli bir hastalık etmeni olan Salmonella ile mücadelede kırmızı alglerin gerek yumurtacı tavuklarda ve gerekse damızlık yumurtaların rasyonlarında kullanılmalarına yönelik çalışmalar oldukça önemlidir. Zira, Kulshreshtha ve ark. (2015) yumurta tavuklarında kırmızı alglerin (Chondrus crispus ve Sarcodiotheca gaudichaudii) kullanımının yumurta tavuklarında Salmonella ile mücadelede etkili olduğunu ispatlamıştır. Yine yumurta tavuklarında Salmonella ile mücadelede $\% 0.5$ ve $\% 1$ fruktooligosakkarit (FOS) uygulaması Salmonella etkeni Salmonella enterica serovar Enteritidis kolonisazyonunu sekumde azaltmıştır (Adhikari ve ark., 2016).

Laktik asit bakteri ile birlikte karışım olarak Bacillus subtilis probiyotiklerinin kullanımı yarkalarda Newcastle disease virus (NDV) ve infectious bursal disease virus (IBDV) hastalıklarına kaşı bağışıklık yanıtının oluşmasına katkı sağlamıştır (Lopera ve ark., 2016).

\section{Sıcaklık Stresinin Olumsuz Etkisini Azaltıcı Besleme}

Hayvanların sicaklık stresinden daha az etkilenmeleri için geleneksel yem çekme uygulamaları yanında, rasyonun enerji içeriğinin yağ ilavesi ile arttırılması ve bunun yanında rasyon protein, esensiyel amino asit, mineral ve vitamin seviyelerini kontrol edilebilir sınırlar içinde bulundurulması, içme suyuna amonyum klorür ve potasyum klorür ilavesi ile kan $\mathrm{pH}$ ve karbondioksit dengesinin sağlanması çalışılan konulardır. $\mathrm{Bu}$ bağlamda; etlik civcivlerde, E vitamini, C vitamini, probiyotik (Attia ve ark., 2017), Koenzim Q (RaeisiZeydabad ve ark., 2017) ve $\mathrm{KCl}$ (Yosi ve ark., 2017) kullanım1, yumurtac1 tavuklarda ise probiyotik karışımının (Zhang ve ark., 2017) sıcaklık stresinin olumsuz etkilerini azalttığına dair yeni çalışmalar mevcuttur.

İçme suyuna ekstra askorbik asit ve elektrolit ilavesi, yemlerin iki aydan fazla depolanmaması, yemlemenin günün serin saatlerin de yapılması, sıcaklığın yüksek olduğu saatlerde hayvanların yemleme ile rahatsız edilmemesi gibi önlemler güncel yaklaşımlar olarak ele alınmaktadır (Rath ve ark., 2015). Tercihli yemleme ve 1slak yemlemenin, etlik civcivlerde vücut 1sısın1 düzenleyerek ve bağırsak sağlığını korumak suretiyle sıcaklık stresini önleyebileceği Syafwan ve ark. (2011) tarafından belirtilmiştir.

\section{Modern Yemleme Uygulamalart}

Karma yem fabrikalarında üretilen yoğun yem karmalarının ekonomik nedenlerle çiftlik bünyesinde de üretilmeye başlanması, yeni pratik bilgi ve uygulamaları da beraberinde getirmiştir. $\mathrm{Bu}$ kapsamda aşağıda değinilen yemleme uygulamaları potansiyel değer arz etmektedir.

\section{Seçmeli Yemleme}

Hayvanlara sunulan yem ham maddelerinden kendi rasyonlarını yapma olanağı veren bir yemleme sistemidir. Pearson kare mantığında olduğu gibi, ihtiyaç duyulan besin maddesi bakımından biri gereksinmenin 
altında diğeri gereksinmenin üzerinde iki yem arasında serbet seçim sunulması halinde hayvanın gereksinmesini karşılayabileceği bu besleme şeklinin temel dayanağıdır (Kutlu, 2014). Hayvanların oluşturdukları kendi yem formülasyonu ile yem fabrikasında uzmanlar tarafindan geliştirilen yem formülasyonu arasındaki farklar (Adrizal ve ark., 2017) seçmeli yemleme çalışmaların odağını oluşturmaktadır. Genetik islah ile her y1l artan yüksek verimli genotiplere ilave olarak son zamanlarda yavaş gelişen yeni genotiplerin üretime dahil edilmesi ile seçmeli veya tercihli yemlemenin diğer bir şekli olan kafeterya usulü yemleme yöntemleri kullanılarak hayvanın kendine özel formülasyon oluşturmasına imkan verilebilir.

\section{Tüm Dane Yemlemesi}

"Whole grain feeding" veya "tüm dane yemleme" olarak bilinen bu yöntemde kullanılan tahıllar temelde protein bakımından fakir enerji kaynaklarıdır. Bunların yaygın olarak kullanımı ancak protein, vitamin ve mineral kaynakları ile yani dengeleyici besin maddeleri ile desteklendikleri takdirde mümkündür (Kutlu, 2014). Konuyla ilgili çalışmalar incelendiğinde, tüm dane tahıl içeren yemleme sistemi ile kanatlı beslemenin pratikte 3 şekilde yapıldığı görülmektedir. Bu yöntemler: 1) karma yem ve tüm dane tahılın aynı anda ancak ayrı yemliklerde seçim esası (choice-feeding) ile sınırsız olarak sunumu, 2) karma yemin ve tüm dane tahılın gün içinde zamana bağlı bir sıra (sequential-feeding) ile aynı yemliklerde sunumu, 3) pelet haldeki karma yemin tüm dane tahıl ile önceden belirlenmiş oranda karıştırılarak (mix-feeding) aynı yemliklerde sunumudur (Kutlu, 2014). Ülkemizde yumurtacı tavuklarda ve etlik piliçlerde bu konuda yapılan çalışmalar yetersizdir.

\section{Grit Yemlemesi}

Hayvan refahı ve taşlık sağlığı için gritin karma yem veya tüm dane yem ile birlikte ya da tercihli olarak sunulmasına ilişkin pozitif sonuçların alındığı hayvan denemeleri yarı ticari ve ticari kümeslerde ArGe kapsamında saha çalışmaları ile desteklenmelidir. Zira, Erener ve ark. (2016), rasyona \%3 çözünmeyen granit grit katılmasının etlik civcivlerde büyüme performansı yanında taşlık gelişimini teşvik ettiğini bildirmişlerdir.

\section{Yem Analizleri ve İzlenebilirlilik}

Yem analizleri, yem sektörünün rasyonel ve ekonomik karma yem formüle edebilmesi ve hayvanların ise yeterli ve dengeli bir şekilde beslenmeleri için yol gösterici ilk enstrümandır. Bu yüzden, hem yem ham maddelerinin hem de üretilen karma yemlerin mutlaka fiziksel, kimyasal ve/veya biyolojik analizlerinin yapılması gerekir. Zira üretilecek karma yemin maliyeti, hayvansal gidaların da maliyetini belirleyen esas unsurdur. $\mathrm{Bu}$ bağlamda, yemlerde besin madde analizi yanında, özgül ağırlık, partikül dağılımı, higroskobik özellik, homojenite, yemde bulunmaması gereken unsurların analizi, karışma ve ayrışma davranışları konuları da önemlidir. Bu konuda öncelikle, akredite yem analiz laboratuvarlarının en azından her bir coğrafi bölge için bir adet kurulması önem arz etmektedir. Daha sonra üretildiği coğrafi bölge ve varyete çeşitliliğine göre, yem ham maddelerin ve sanayii yan ürünlerinin analize dayalı besin madde içerik tablolarını içeren ulusal yem hammaddeleri veri bankasının oluşturulması için çalışmaların başlatılması yerinde olacaktır. Ayrıca, veri bankası bünyesinde NIR gibi hızlı analiz tekniklerinin güvenilirliğinin geliştirilmesi, buna yönelik kalibrasyon çalışmaları ve klasik analiz sonuçları ile uyumluluğunun kontrolü büyük önem taşımaktadır.

Birleşmiş Milletler Gıda ve Tarım Örgütü (FAO) ile Uluslararası Yem Endüstirisi Federasyonu (IFIF) tarafindan 2010 yılında hazırlanan bir klavuzda (Good practices for the feed industry - Implementing the Codex Alimentarius Code of Practice on Good Animal Feeding) hem endüstriyel hem de çiftlikte iyi yem üretimi, iyi hayvan besleme uygulamaları ve izlenebilirlilik konusu detaylıca tarif edilmiştir (FAO ve IFIF, 2010). İzlenebilirliğin üretim akış şemasının herhangi bir noktasından ilk, ara veya son üründen elde edilecek örnekler bazında değerlendirilmesi durumunda ülkemizde akredite olmuş laboratuvar yetersizliğinden söz etmek yerinde olacaktır.

\section{Sonuç ve Öneriler}

Tavukçuluk ve karma yem alanında, Ülkemizde ve Dünyada yapılan akademik çalışmalar ve gelişmeler dikkate alındığında aşağıdaki öneriler ön plana çıkmaktadır;

- $\quad$ Ülkemizde yem sanayinin ve özellikle kanatlı sektörünün yem hammadde açığı bulunmaktadır. Bu da bitkisel üretimin yetersizliğinden ve bitkisel üretim desenlerinin yöresel ve bölgesel ihtiyaçlara göre dizayn edilmemesinden ileri gelmektedir. $\mathrm{Bu}$ sorunu, en azından yöresel veya bölgesel konjüktürde çözebilmek için; ilgili sektörler sözleşmeli tarımla istedikleri ham maddeleri alım garantisi ile ürettirerek, hem ülkemiz tarım arazilerinin daha etkin kullanımını sağlanabilir ve hem de döviz kaybının 
önüne geçilebilir.

- Kanatlı beslemede protein açı̆̆ının kapatılmasında, üç tarafı denizle çevrili ülkemizde, "balık unu" kullanımını daha ucuz hale getirici işleme ve tedarik yolları araştırılmalı ve geliştirilmelidir.

- Biyoyakıt üretiminden elde edilen yan ürünlerin, kanatlı beslemede daha etkin kullanımına yönelik bilimsel çalışmalar yapılmalıdır.

- $\quad$ Bitki ve hayvanlardaki genetik ilerlemeler ile çevresel değişimler veya zenginleştirmeler, kanatlı hayvanların besin madde gereksinimlerinde ve yem ham maddelerinin besin madde içerik tablolarında güncelleştirmeyi zorunlu kılmaktadır.

- $\quad$ Başta hindi olmak üzere, kaz, ördek, bıldırcın gibi diğer kanatlı türlerinin beslenmelerinde daha fazla yöresel yem ham maddeleri kullanılabilir.

- Meraya dayalı serbest dolaşımlı tavukçuluk için; tek yıllık ve çok yıllık yem bitkilerinden oluşan suni meraların tesisi gibi yeni çalışmalara da gereksinim vardır. Bu kapsamda, yonca, çayır yumağı, tek yıllık çim ve üçgül öne çıkan yem bitkileridir.

- Kanatlı hayvanlar üzerinde olumlu etkileri ispatlanmış, ülkemiz tıbbi ve aromatik bitkilerinden, ticari patentli veya tescilli ve gerek ülkemizde ve gerekse yurt dışında dolaşımını sağlayacak yeni yem katkısı kokteylerin tavukçuluk sektörünün kullanımına takdim edilmesine dair çalışmalar hizlandırılmalıdır.

- Her bir coğrafi bölgemiz için en az bir akredite olmuş yem ve gıda analiz laboratuvarların ÜniversiteGıda, Tarım ve Hayvancılık Bakanlığı veya Üniversite-Gümrük ve Ticaret Bakanlığı ile afiliasyon dahilinde işletilmesi ile yem ve gıda güvenliği ile ilgili ve özellikle beslenme hastalıkları ile ilgili hukuki çıkmazların aydınlatılmasına katkı sağlanacaktır. Ayrıca, limanlardan alınan ithal yem ham maddelerinin besin madde ve kalıntı madde analizleri daha kısa süre içinde tamamlanabilecektir.

- Yem-gida zincirinde yem kısmının güvence altına alınması için; hem endüstriyel hem de çiftlikte iyi yem üretimi, iyi hayvan besleme uygulamaları ve izlenebilirlilik süreçlerini içeren kapsamlı bir klavuz hazırlanmalıdır.

Sonuç olarak; kanatlı besleme alanında yürütülmesi planlanan araştırmalar, yalnızca alanıyla ilgili teorik bilime ve pratik saha uygulamalarına değil, ülkemiz gündeminde yer alan tartışmalı konulara, tüketici sağlığ 1 ve ekolojik dengenin korunmasına da katkı sağlayacak nitelikte olmalıdır.

\section{Kaynaklar}

Abbas, T.E.2013. The use of Moringa oleifera in poultry diets. Turk J Vet Anim Sci 37: 492-496.

Abdollahi, M.R.2011.Influence of feed processing on the performance, nutrient utilisation and gut development of poultry and feed quality. $\mathrm{PhD}$ Thesis. Massey University, Palmerston North, New Zelanda.

Adhikari, A.,Cosby, D.E., Cox,N.A., Kyun, W.K.2016.Effect of fructoligosaccharides on colonization of the ceca,liver/gall bladder, and ovary plus fecal shedding and ileum morphology in hens challenged with Salmonella Enteritidis. Poult. Sci. 95 (E-Suppl. 1):3.

Adrizal, A., Syafwan, S., Noferdiman, N., Zubaida, S.,Pasaribu, T.M.2017. Energy and Protein Consumption and Utilization of Local Female Chicken Reared Under Semi-Scavenging System in the Tropics. Proceedings of the $21^{\text {st }}$ European Symposium on Poultry Nutrition.

Attia Y.A., Al-Harthi M.A., El-Shafey A.S., Rehab, Y.A., Woo, K. K. 2017. Enhancing tolerance of broiler chickens to heat stress by supplementation with vitamin $\mathrm{E}$, vitamin $\mathrm{C}$ and/or probiotics, Annals of Animal Science, DOI: 10.1515/aoas- 2017-0012.

Beski, S.S.M., Swick, R.A., Iji, P.A.2015.Specialized protein products in broiler chicken nutrition: A review. Animal Nutrition 1:47-53.

Blanco, J.A. 2013. Chapter: 3.2. Fodder and Animal Feed. http://www.fao.org/3/a-i4042e/i4042e15.pdf, erişim tarihi 16.07.2017.

Bohórquez, D.V.2010.Nutritional Influences on the Ultra-structural Development of the Small Intestinal Epithelium of the Perinatal Turkey Embryo and Poult. PhD Thesis. North Carolina State University, North Caroline.

Bölükbaşı, Ş.C., Al-sagan, A.A., Ürüşan, H., Erhan, M.K., Kurt, N.2016. Effects of cerium oxide supplementation to laying hen diets on performance, egg quality, some antioxidant enzymes in serum and lipid oxidation in egg yolk. Journal of Animal Physiology and Animal Nutrition 100:686-693.

Carneiro, P. R. O.,. Hadinia, S. H., Gilmet, T. E. , Zuidhof. M. J. 2015. Effect of precision feeding on 
broiler breeder uniformity and efficiency. Poult. Sci. 94 (E-Suppl. 1):1.

Caly, D.L., D'lnca, R., Auclair, E., Drider, D. 2015. Alternatives to Antibiotics to Prevent Necrotic Enteritis in Broiler Chickens: A Microbiologist's Perspective. Frontiers in Microbiology 6 (Article 1336):1-12.

Çayan, H., Erener, G.2015.Effect of Olive Leaf (Olea europaea) Powder on Laying Hens Performance, Egg Quality and Egg Yolk Cholesterol Levels. Asian Australas. J. Anim. Sci. 28 (4) : 538-543.

Chabrillat, T., Cadudal, B., Recoquillay, F, Gourguechon, A.,Kerros, S. 2017. Utilization of plant extracts instead of chemical growth promoters and coccidiostats for broilers. 21 ${ }^{\text {st }}$ Europen Symposium on Poultry Nutrition.

Cherian, G.2015. Nutrition and metabolism in poultry: role of lipids in early diet. J Anim Sci Biotechnol. 6(1): 6-28.

Coşkun, İ., Erener, G., Şahin,A., Karadavut, U., Altop, A., Okur, A.A.2014a. Impacts of In Ovo Feeding of DL-Methionine on Hatchability and Chick Weight. Turkish Journal of Agriculture - Food Science and Technology 2(1): 47-50.

Coşkun, İ., Çayan, H., Yılmaz,Ö., Taşkın, A., Tahtabiçen, E., Şamli, H.E.2014b. Effects of In Ovo Pollen Extract Injection to Fertile Broiler Eggs on Hatchability and Subsequent Chick Weight. Türk Tarım ve Doğa Bilimleri Dergisi 1(4): 485-489.

Coşkun, İ., Tad, M., Filik G., Altop,A., Şahin, A., Erener, G., Şamli, H.E.2017. Dietary symbiotic supplementation alters the ileal histomorphology and caecal pathogen micro-organism in broiler chicks. Journal of Livestock Science 8: 109-114.

De Keyser, K., Kuterna, L., Kaczmarek, S., Rutkowski, A., Vanderbeke, E., 2016. High dosing NSP enzymes for total protein and digestible amino acid reformulation in a wheat/corn/soybean meal diet in broilers. J. Appl. Poult. Res. 25:239-246.

Deep, A., Schwean-Lardner,K., Kessel,A.G.W., Classen, H.L.2015. Feeding pea enhances the degree of satiety in feed restricted broiler breeder pullets. Poult. Sci. 94 (E-Suppl. 1):21.

Dida, M.F.2016. Review Paper on Enzyme Supplementation in Poultry Ration. International Journal of Bioorganic Chemistry 1(1):1-7.

Durmuş,O., Bölükbaşı, Ş.V.2015. Biological activities of lanthanum oxide in laying hens. The Journal of Applied Poultry Research 24 (4):481-488.

Dündar, Y. 2001. Fitokimyasallar ve sağlıklı yaşam. Kocatepe Tip Dergisi 2:131-138.

Erener,G., Coşkun,I., Ayşenur, A.2015. The effects of in ovo injection lysine and methionine to fertile broiler eggs on hatchability growth performance gastro intestinal tract development gut microbiota and ileal histomorphology. $7^{\text {th }}$ Balkan Conference on Animal Science. BALNIMALCON, Ilıdza-Sarajevo.

Erener,G., Ocak,N., Garipoğlu,A.V., Şahin, A.2016. Insoluble granite-grit allows broiler chicks to have better growth performance and gut health. R. Bras. Zootec. 45(11):650-654.

Ergul, T., Martinez Amezcua, C., Parsons, C. M., Walters, B., Brannon, J., Noll, S.L. 2003. Amino acid digestibility in corn distillers dried grains with solubles. Poultry Sci. 82 (Suppl. 1): 70.

Erlwanger, K.H., Unmack, M.A., Grøndahl, M.L., Pierzynowski, S.G., Aalbaek, B., Dantzer, V., Skadhauge, E.1999.Effects of dietary substitution with raw and heat-treated cowpea (Vigna unguiculata) on intestinal transport and pancreatic enzymes in the pig. Zentralbl Veterinarmed A. 46(10):581-92.

FAO ve IFIF. 2010. Good practices for the feed industry - Implementing the Codex Alimentarius Code of Practice on Good Animal Feeding. FAO Animal Production and Health Manual No. 9. Rome.

Ferzola, P.H., Oviedo-Rondón,E.O., Sarsour,A., Cordova, H.A.2016. Cordova, Sorghum inclusion levels and the addition of a serine protease on footpad dermatitis at 40 days of age. Poult. Sci. 95(E-Suppl. 1):7.

Galea, F.2011.Nutrition and food management and their influence on egg quality. XLVIII Simposio Cientifico De Avicultura. Santiago de Compostela, 5 al 7 de Octubre de 2011.

Gorski,F., Utterback, P.L., Parsons,C.M.2015. Nutritional evaluation of canola meal produced from a new variety of canola seeds in broiler chickens and laying hens. Poult. Sci. 94 (E-Suppl. 1):34.

Gupta, S., Mehta, M. 2016. Effect of cysteine protease enzyme in diet to reduce soybean meal without affecting performance of Kadaknath birds in India. Poult. Sci. 95 (E-Suppl. 1):9.

Gül,M., Tekce, E.2016. Hayvan Beslemede Yeni Bir Yem Maddesi; Kinoa. Yem Magazine 24(76):29-35. 
Hamidi, O., Chamani, M., Ghahri, H.,Sadeghi, A.A., Malekınejad, M.2016. Effects of chromium (III) picolinate and chromium (III) picolinate nanoparticles supplementation on growth performance, organs weight and immune function in cyclic heat stressed broiler chickens. Kafkas Univ. Vet. Fak. Derg. 22 (3): 373-380.

Hwangbo,J., Hong,E.C., Jang,A., Kang,H.K., Oh, J.S., Kim, B.W., Park, B.S.2009.Utilization of house flymaggots, a feed supplement in the production of broiler chickens. Journal of Environmental Biology 30(4): 609-614.

Kana, R.J., Teguia, A., Fomekong, A. 2012. Effect of substituting soybean meal with cowpea (Vigna unguiculata wal) supplemented with natural plant charcoals in broiler diet on growth performances and carcass characteristics. Iranian Journal of Applied Animal Science 2(4):377-381.

Kathirvelan,C., Janani,S.R., Ramesh, J., M.R. Purushothaman.2015. Significance of usage of phytase in poultry nutrition. International Journal of Science and Technology 4 (4): 1214 - 1217.

Keser, O., Bilal, T.2010. İnülinin kanatlı beslemede kullanılması. Kafkas Univ Vet Fak Derg 16 (4): 685 695.

Kheravii, S., K., Swick,R.A., Choct,M., Wu,Ş.B.2016. The changes of short-chain fatty acids and cecal bacteria in response to a lignocellulose supplementation in wheat or corn based diet. Poult. Sci. 95(E-Suppl. 1):14.

Korwin-Kossakowska,A., Sartowska,K., Linkiewicz, A., Tomczyk,G., Prusak, B., Sender, G.2013. Evaluation of the effect of genetically modified Roundup Ready soya bean and MON 810 maize in the diet of Japanese quail on chosen aspects of their productivity and retention of transgenic DNA in tissues. Archiv Tierzucht 56 (60): 597-606.

Kulshreshtha, G., Rathgeber, B., Boulianne, M., Brigitte, L., Stratton, G., Thomas N., Critchley, A., Hafting, J., Prithiviraj, B.2015. Feed supplementation with the red seaweeds Chondrus crispus and Sarcodiotheca gaudichaudii reduce Salmonella Enteritidis in layer hens. Poult. Sci. 94 (E-Suppl. 1):27.

Kutlu, H.R. 2014. Tavukların Beslenmesi. In: M.Türkoğlu ve M. Sarıca (Editör), Tavukçuluk Bilimi (Yetiştirme, Besleme ve Hastalıklar), 4. Baskı, Bey Ofset Matbacilık, Ankara, pp.405-560.

Kutllu, H.R. 2017. Effect of multienzyme produced by a single fungus on growth performance and some carcass parameters of broiler chicks. Unpublished results.

Kutlu, H.R., Çelik, L. 2016. Yemler Bilgisi ve Yem Teknolojisi. Ç.Ü. Ziraat Fakültesi Genel Yayın No:266, Ders Kitapları Yayın No:A-86, Adana.

Kutlu, H.R., Özen, N.2009. Hayvan Beslemede Son Gelişmeler (Çağrılı Bildiri). VI. Ulusal Zootekni Bilim Kongresi 24-27 Haziran 2009, Atatürk Üniv. Erzurum,72 sayfa.

Kutlu, H.R., Unsal, I, Gorgulu, M. 2001. Effects of providing dietary wood (oak) charcoal to broiler chicks and laying hens. Anim.Feed Sci.Tech. 90: 213226

Kur, A.T.Y., Abdelatti, K.A., Dousa, B.M., Elagib, H.A.A., Malik, H.E.E, Elamin, K.M.2013. Effect of Treated Cowpea Seeds on Broiler Chicken. Global Journal of Animal Scientific Research 1(1):58-65.

Liu, S.Y., Selle, P.H., Cowieson, A.J. 2014. Influence of steam-pelleting temperatures and grain variety of finely-ground, sorghum-based broiler diets on small intestinal starch and nitrogen digestion dynamics in broiler chickens. International Journal of Poultry Science 13 (6): 308-315.

Lopera,P.A., Rodriguez-Lecompte,J.C., Reyes, J.2016. Modulation of adaptive immune responses by probiotics in chicken pullets. Poult. Sci. 95 (E-Suppl. 1): 3 .

Maiorano, G., Bednarczyk, M.2016.Prebiotics and synbiotics in broiler chicken production:in vivo performance and meat quality aspects: A review. Slovak J. Anim. Sci. 49 (4): 151-156.

Malomo, O. 2013. Effect of processing on component oligosaccharides of cowpea (Vigna unguicustala). Research and Reviews: Journal of Food and Dairy Technology 1(1):33-36.

Mazaheri, A., Shams Shargh, M., Dastar, B.,Zerehdaran, S. 2014. Effect of different levels of mushroom waste (Agaricus bisporus) with or without probiotic on growth performance, carcass characteristics, and breast meat quality in broiler chickens. Poultry Science Journal 2 (2): 125-138.

McDowell, L.R., Ward, N.E.2011. Optimum vitamin nutrition for poultry.International Poultry Production $16(4): 27-34$.

Min, Y.N., F.Z. Liu, Z. Wang, C. Coto, S. Cerrate, F.P. Costa, F. Y., Waldroup, P.W. 2008. Evaluation of distillers dried grains with solubles in combination 
with glycerin in broiler diets. Int. J. Poult. Sci. 7: 646654.

Muthamilselvan,T., Kuo,T.F., Wu,Y.C., Yang, W.C.2016.Herbal Remedies for Coccidiosis Control: A Review of Plants, Compounds, and Anticoccidial Actions. Evidence-Based Complementary and Alternative Medicine (Article 2657981):1-19.

NRC,1994. National Research Council Nutrient Requirements of Poultry - Ninth Revised Edition.

Olaiya, C.O., Soetan, K.O.2014. A review of the health benefits of fenugreek (Trigonella foenum-graceum L.): Nutritional, biochemical and pharmaceutical perspectives. American Journal of Social issues and Humanities Special Issue Mar/Apr, 3-12.

Olukosi, O.A.2012. Biochemistry of phytate and phytases: Applications in monogastric nutrition. Biokemistri 24 (2): 58-63.

Özcan, M.A.2014.Gümüş Nanopartiküller ve Kanatlı Hayvan Beslemede Kullanımına Yönelik Çalışmalar.Tavukçuluk Araştırma Dergisi 11 (2): 1620.

Raeisi-Zeydabad, S., Mirmahmoudi, R., Esmaeilipour, O., Mazhari, M. 2017. Effects of Coenzyme Q10 and Vitamin C on Growth Performance and Blood Components in Broiler Chickens under Heat Stress. Poult. Sci. J. 5 (2): 63-70.

Rath, P.R., Behura,N.C., Sahoo,S.P.,Panda,P.,Mandal, K.D., Panigrahi, P.N.2015.Amelioration of Heat Stress for Poultry Welfare: A Strategic Approach. International Journal of Livestock Research 5(3):1-9.

Robinson, K., Sunkara, L., Zhang,G.2016. Regulation of host defense peptide expression and barrier function by butyrate and FSK in broiler chicks. Poult. Sci. 95 (E-Suppl. 1):4.

Schramm, V.G., Durau,J.F., Massuquetto, A.,Zavelinski,V.A.B., Fascina,V.B., Maiorka,A. 2016. Amylase improves digestibility of pelleted diets. Poult. Sci. 95 (E-Suppl. 1):11.

Shariatmadari, F., Forbes, J.M.2005. Performance of broiler chickens given whey in the food and/or drinking water. British Poultry Science 46 (4): 498 505.

Singletary, K.W.2017.Fenugreek Overview of Potential Health Benefits. Nutrition Today 52(2):93-111.

Smith, K.A., Jasek, A.T., Wyatt,C., Lee, J.T.2016. Evaluation of increasing levels of phytase in diets containing variable levels of amino acids on male broiler performance and processing yields. Poult. Sci.
95(E-Suppl. 1):9.

Singh, A.K., Berrocoso,J.D., Kida,R., Kim, Y.S., Jha,R.2016. In ovo inoculation of raffinose improves hatchability, vitalizes gut mucosa, and enhances immune response in broiler chickens. Poult. Sci. 95(E-Suppl. 1):4.

Spencer, T.2013. Pastured Poultry Nutrition and Forages. ATTRA (attra.ncat.org) :1-20.

Suchy, P., Straková, E., Herzig, I.2014. Selenium in poultry nutrition: a review. Czech J. Anim. Sci. 59 (11): 495-503.

Surai, P.F.2002a.Natural Antioksidants in Avian Nutrition and Reproduction. Nothingham University Press, Nothingham.

Surai P.F. 2002b. Selenium in poultry nutrition: a new look at an old element. 2. Reproduction, egg and meat quality and practical applications. World's Poultry Science Journal 58: 431-450.

Surai, P.F.2012.Natural antioksidants in Poultry Nutrition: New developments. $16^{\text {th }}$ Europen Symposium on Poultry Nutrition: 669-676.

Swiatkiewicz, S., Swiatkiewicz, M., ArczewskaWloseka,A., Jozefiak, D. 2014. Genetically modified feeds and their effect on the metabolic parameters of food-producing animals: A review of recent studies. Animal Feed Science and Technology 198:1-19.

Świątkiewicz, S., Arczewska-Włosek, A., Józefiak, D.2015a.Application of microalgae biomass in poultry nutrition. World's Poultry Science Journal 71:663-672.

Światkiewicz, S., Swiatkiewicz, M., Arczewska-Wlosek, A., Jozefiak, D. 2015b. Chitosan and its oligosaccharide derivatives (chito-oligosaccharides) as feed supplements in poultry and swine nutrition. Journal of Animal Physiology and Animal Nutrition 99:1-12.

Syafwan, S., Kwakkel, R.P., Verstegen, M.W.A.2011.Heat stress and feeding strategies in meat type chickens. World's Poultry Science Journal 67: 653-673.

Tadondjou,C.D., Ngoula,F., Kana, J.R., Defang, H.F., Mube, H.K., Teguia, A.2013. Effect of dietary energy level on body weight, testicular development and semen quality of local barred chicken of the western highlands of Cameroon. Advances in Reproductive Sciences 1(3):38-43.

TMO, 2016. Toprak Mahsulleri Ofisi Genel Müdürlüğü 2016 Y1lı Hububat Raporu, 207 sayfa. 
Tunçer, P.2012. Mersin bitkisinin (Myrtus communis L.) broyler rasyonlarında kullanım imkanlarının araştırılması. Doktora Tezi. Afyon Kocatepe Üniversitesi. Sağlık Bilimleri Enstitüsü, Afyonkarahisar.

Uni, Z. 2003. Methods for early nutrition and their potential.14 ${ }^{\text {th }}$ Euro. Symp. Poultry. Aug. Norway

USGC,2012.DDGS Kullanıc1 el kitabı. ABD Tahıl Konseyi (Çeviren: Nadir Fayazoff), 92 sayfa.

Vlaicu, P.A., Dragotoiu, D., Panaite, T.D., Untea, A., Saracila, M., Mitoiu, M.2017. Effect of rosehip addition to $\Omega 3$ PUFA-high layer diets on hen performance and egg quality. Proceedings of the $21^{\text {st }}$ European Symposium on Poultry Nutrition.
Yagoub, Y.M.1998.Effect of piegon pea and cow pea on the performance and gut immunity of broiler chicks. MSc Thesis. Faculty of Animal Production,University of Khartoum.

Yosi,F., Widjastuti, T., Setiyatwan, H. 2017. Performance and physiological responses of broiler chickens supplemented with potassium chloride in drinking water under environmental heat stress. Asian J. Poult. Sci. 11: 31-37.

Zhang,P., Yan,T., Wang, X., Kuang, S., Xiao, Y., Lu, W., Bi, D.2017. Probiotic mixture ameliorates heat stress of laying hens by enhancing intestinal barrier function and improving gut microbiota, Italian Journal of Animal Science 16:2:292-300. 